\title{
ATENÇÃO CARO LEITOR, PEDALAR FAZ MAL À SAÚDE!
}

Coluna publicada em 23.9.2014: <http://www.conjur.com.br/2014-set-23/ contas-vista-atencao-caro-leitor-pedalar-faz-mal-saude $>$

Acalme-se, não é o que está pensando...

Não escreverei sobre ciclismo, como pode parecer.

Portanto, se você é paulistano, não se preocupe com as dezenas de quilômetros de ciclovias que estão aparecendo na porta de casa - elas podem até complicar ainda mais o trânsito, mas com certeza vão ajudar a melhorar a sua saúde!

Também não pretendo falar de futebol, afinal Robinho voltou à seleção, quem sabe voltemos a ver algumas pedaladas que possam nos ajudar a chegar ao hexa.

$\mathrm{O}$ assunto continua sendo o Direito Financeiro.

A saúde a que me refiro é a das nossas finanças públicas, que está ficando seriamente comprometida com as "pedaladas fiscais" do governo, objeto de grande preocupação para todos os que acompanham as atividades financeiras do setor público.

Pedalada fiscal é "a prática recorrente de atrasar o pagamento de serviços prestados por fornecedores do setor público, atrasos no repasse dos ministérios setoriais para que bancos públicos e privados paguem os benefícios sociais e postergação no pagamento de subsídios devido a bancos públicos". ${ }^{1}$ Correspondem, em verdade, a um conjunto de medidas que, no mais das vezes, representam operaçóes financeiras realizadas pelo governo, de diversas formas, com vistas a obter de modo artificial resultados aparentemente melhores nas contas públicas.

1 ALMEIDA, Mansueto. Pedaladas fiscais. Blog do Mansueto Almeida, <http://mansueto.wordpress.com/2014/08/29/pedaladas-fiscais/> 
O assunto está sendo levantado e debatido na mídia nas últimas semanas, como se pode constatar das várias reportagens, colunas e artigos, alguns dos quais citados ao longo deste texto.

São fortes os indícios de que as contas públicas vão de mal a pior, e, em vez de se tomarem medidas voltadas a combater as causas do problema, o que se tem visto são tentativas de esconder esses fatos, verdadeiramente "jogando a sujeira para debaixo do tapete", para ocultar as mazelas e tentar ludibriar a todos. Seguramente motivadas pela proximidade das eleições, em que notícias ruins podem levar a perda de votos, atitudes que prejudicam o setor público acabam sendo tomadas, provocando irremediáveis prejuízos à credibilidade das contas públicas e à segurança do ordenamento jurídico.

O caso traz questôes interessantes sob o ponto de vista do Direito Financeiro, especialmente no que se refere à aplicabilidade de dispositivos da Lei de Responsabilidade Fiscal e ao relacionamento entre os próprios entes governamentais.

Tem sido constatado que diversos pagamentos sob responsabilidade do governo federal, como os benefícios sociais e previdenciários, bolsa-família e outros, operacionalizados por bancos públicos, especialmente a Caixa Econômica Federal e o Banco do Brasil, são regularmente efetuados pelas instituições financeiras, sem que o Tesouro lhes tenha repassado o recurso correspondente. Isso representaria uma antecipação dos pagamentos, feitos pelos bancos, de despesas governamentais. Um verdadeiro uso, pelo governo federal, de um "cheque especial". ${ }^{2} \mathrm{O}$ fato já foi inclusive objeto de representação por parte do Ministério Público junto ao TCU perante este tribunal, com vistas a apurar os fatos e tomar as medidas cabíveis, ${ }^{3}$ já tendo sido iniciada a investigação. ${ }^{4}$

Tal como o pai de família que se vê sem condições de pagar as contas no final do mês, e sem perspectivas de ajustar suas finanças no curto prazo, passando a fazer uso do cheque especial para financiar suas despesas, o governo tem se valido dessas medidas para "maquiar" as contas públicas, postergando o registro dos gastos, de modo a produzir números que não refletem a realidade das finanças governamentais.

Atrasos nos desembolsos para pagar obras do Programa de Aceleração do Crescimento (PAC), como tem sido registrado pelas empreiteiras, somados a pressões do governo federal sobre o BNDES para pagar dividendos devidos ao

2 GIANETTI, Eduardo. Imbróglio fiscal. Folha de S.Paulo, 29 de agosto de 2014.

3 Representação do Procurador Júlio Marcelo de Oliveira, em 21 de agosto de 2014.

4 TCU investiga "pedaladas fiscais" do governo. O Estado de S.Paulo, 18 de setembro de 2014. 
Tesouro 5 mostram a promiscuidade nas relações entre o governo, seus órgãos, entidades da administração indireta, bancos públicos, compondo um quadro que evidencia "malabarismos" para apresentar contas públicas "palatáveis".

Voltam a aparecer as técnicas de "contabilidade criativa" sobre a qual já nos referimos há mais de um ano na coluna Carnaval financeiro: contas maquiadas não vão tornar nosso país mais bonito, nesta edição, p. 387-390, em que mostramos que o país já teve sua credibilidade abalada pelas operações realizadas no início do ano passado, problema que agora retorna com "pedaladas" que só ajudam a acelerar na direção errada.

Essas antecipações configuram operações de crédito entre o governo e referidas instituiçôes, ao adiantar recursos para serem pagos posteriormente. E não é pouco dinheiro. Há estimativas de que o Tesouro está retendo $\mathrm{R}$ \$ 60 milhões que deveriam ter sido repassados aos bancos públicos. ${ }^{6}$

Remetem à discussão sobre a legalidade dessas operaçôes, uma vez que a Lei de Responsabilidade Fiscal (LRF), em seu artigo 35, veda "a realização de operação de crédito entre um ente da Federação, diretamente ou por intermédio de fundo, autarquia, fundação ou empresa estatal dependente, e outro, inclusive suas entidades da administração indireta, ainda que sob a forma de novação, refinanciamento ou postergação de dívida contraída anteriormente". Este artigo, seguindo o espírito da LRF, e que tem sido importante para a gestão responsável, traz vedação a ato potencialmente gerador de descontrole das finanças públicas e prejudicial à transparência e credibilidade das finanças públicas, no que se encaixam com perfeição as "pedaladas fiscais".

Embora esse dispositivo tenha sido objeto de questionamento sob alguns pontos de vista, especialmente no que se refere à violação do princípio federativo, por veicular proibição que pode mitigar a autonomia financeira dos entes federados, que se veem impedidos de realizar muitas atividades financeiras úteis para gerenciar seus recursos, 7 não é a hipótese em questão, por serem as "pedaladas fiscais" operações feitas pelo próprio governo federal com suas entidades, deixando clara a ilegalidade dos atos praticados.

O caso chama a atenção também para outra questão: os poucos conhecidos e divulgados "litígios intragovernamentais", muitas vezes até judicializados, que

5 Pendura do Tesouro no PAC. O Estado de S.Paulo, 26 de agosto de 2014.

6 Pedaladas de marcha a ré. Revista Veja, Edição digital, n. 2.391, de 17 de setembro de 2014, seção Economia.

7 Veja-se a ADI 2.250, movida pelo Governo de Minas Gerais, cujo mérito está pendente de julgamento. 
usualmente envolvem matéria financeira, com a disputa entre entes do próprio governo, como o que houve entre a Caixa Econômica Federal e o Tesouro. Deu origem inclusive à criação da Câmara de Conciliação e Arbitragem da Administração Federal (CCAF), no âmbito da Advocacia Geral da União, "para dirimir, por meio de conciliação, as controvérsias entre órgãos e entidades da Administração Pública Federal, bem como entre eles e a Administração Pública dos estados, do Distrito Federal, e dos municípios", além de "buscar a solução de conflitos judicializados, nos casos remetidos pelos Ministros dos Tribunais Superiores e demais membros do Judiciário, ou por proposta dos órgãos de direção superior que atuam no contencioso judicial". ${ }^{8}$ As "pedaladas fiscais" foram levadas pela Caixa Econômica Federal ao CCAF, ante o receio dos dirigentes de serem responsabilizados pelas ilegalidades, com vistas a obter respaldo jurídico para as operações.?

O fato é que os especialistas no assunto não se deixam enganar facilmente, e essas manobras novamente fizeram as agências de risco rebaixar as nossas "notas" junto aos investidores internacionais $;^{10}$ mas o pior é ver o desrespeito ao ordenamento jurídico financeiro e quebra da segurança jurídica.

As "pedaladas fiscais" foram lançadas ironicamente por Mailson da Nóbrega, ex-presidente do Banco Central, para concorrer ao "Prêmio Ig Nobel" de contabilidade criativa, ${ }^{11}$ e só faltava ganharmos essa para passarmos mais vergonha depois $\operatorname{dos} 7$ a 1.

Enquanto isso, é melhor cuidarmos da nossa saúde, tirando as bicicletas da garagem para dar umas pedaladas e aproveitar as ciclovias, pois elas estão aí e tudo indica que vieram para ficar, já que, em relação à saúde das contas públicas, a situação está bem mais complicada...

8 Decreto 7.392/2010, art. 18. Sobre o tema, veja também o trabalho de Arnaldo Godoy, Domesticando o Leviatã: litigância intragovernamental e presidencialismo de articulação institucional. Tese de Livre-docência, Faculdade de Direito da USP, 2012.

9 Caixa é pressionada a recuar em pedalada. O Estado de S.Paulo, em 3 de setembro de 2014.

10 Efeito dominó. Folha de S.Paulo, em 22 de agosto de 2014.

11 NÓBREGA, Maílson. Prêmio Ig Nobel de contabilidade criativa. Revista Veja, ed. 2.389, 3 de setembro de 2014, p. 22. 